mgr inż. Jarostaw Królikowski,

dr inz. Rafat Cichy,

mgr inz. Michat Kowalski

Instytut Pojazdów Szynowych "TABOR"

\title{
Proposal of legal regulations of trams modernization taking into account the experiences and provisions applicable in railway rolling stock
}

\section{Propozycja regulacji prawnych dla modernizacji tramwajów z uwzględnieniem doświadczeń i przepisów obowiązujących $\mathbf{w}$ taborze kolejowym}

The article presents a procedure when introducing modifications to the types of trams that have a valid type approval certificate in the context of the law in Poland. The method of introducing modifications to railway vehicles is also presented. The article aims to present an alternative approach to the problem of tramway modernization, taking into account the requirements of Polish law and experience related to other types of railway vehicles.

$W$ artykule zaprezentowano sposób postępowania przy wprowadzaniu modyfikacji $w$ typach tramwajów posiadajacych aktualne świadectwo homologacji w kontekście przepisów prawa w Polsce. Przedstawiono również sposób wprowadzania modyfikacji w pojazdach kolejowych. Artykut ma na celu przedstawienie alternatywnego sposobu podejścia do zagadnienia modernizacji tramwajów przy uwzględnieniu wymogów prawa polskiego oraz doświadczeń zwiazanych z innymi rodzajami pojazdów szynowych.

\section{INTRODUCTION. PROVISIONS REGULAT- ING THE TYPE APPROVAL OF TRAM- WAYS}

Trams as railway vehicles are one of the most popular vehicles used in public transport in large agglomerations in Poland. They are present in virtually every major city. Currently, there are 15 tram networks in Poland in the following locations:

- Szczecin

- Gorzów Wielkopolski

- Poznań

- Wrocław

- Gdańsk

- Elblag

- Grudziądz

- Bydgoszcz

- Toruń

- Warszawa

- Łódź

- Częstochowa

- Kraków

- Upper Silesian Industry District

- Olsztyn

Unfortunately, not all tram networks are unified, they differ with track widths, and loading gauge.

\section{WSTĘP. PRZEPISY REGULUJĄCE HOMO- LOGACJĘ TRAMWAJÓW}

Pojazdy szynowe, jakimi są tramwaje, są jednym z najpopularniejszych środków transportu używanych $\mathrm{w}$ komunikacji miejskiej w dużych aglomeracjach w Polsce. Są obecne praktycznie w każdym większym mieście. Obecnie w Polsce znajduje się 15 sieci tramwajowych w następujących lokalizacjach:

- Szczecin

- Gorzów Wielkopolski

- Poznań

- Wrocław

- Gdańsk

- Elbląg

- Grudziądz

- Bydgoszcz

- Toruń

- Warszawa

- Lódź

- Częstochowa

- Kraków

- GOP (Górnośląski Okręg Przemysłowy)

- Olsztyn

Niestety, nie wszystkie sieci są zunifikowane, różnią się między sobą m.in. rozstawami torów, skrajnią taboru. 
Due to these differences, it is not always possible to produce vehicles that could move across all the tram tracks in the country.

However, despite the differences, vehicles moving on these networks are subject to the same legal requirements. Regulations regulating the type approval of trams in Poland were issued on the basis of the Act of 20 June 1997 Traffic Law, which are:

- Regulation of the Minister of Transport and Maritime Economy of May 28, 2013 on type approval of trams and trolleybuses (Journal of Laws of 2015, item 38).

- Regulation of the Minister of Infrastructure of March 2, 2011 regarding the technical conditions of trams and trolleybuses and the scope of their necessary equipment (Journal of Laws of 2011 No. 65, item 344)

The document confirming that the tram type has met all of the above requirements is the vehicle type approval certificate. As part of the certificate issued, important features differentiating the type, variant or version of the tram were defined and presented as follows:

- type - includes vehicles for which all are common, the following features:

omanufacturer

ofactory type designation

omain structural considerations, including:

- car body construction (obvious and basic differences)

- main traction drive (electric traction powered or electric autonomous)

- number of tram members

- variant - it includes all vehicles within the vehicle type for which all of the following construction features are common:

$\circ$ tram type (motored, trailer active, trailer passive)

o tram movement direction (one-way or twoway)

○ nominal voltage supply

o track width

o bogies or chassis (significant construction characteristics)

○ axle drive (number, location, kinematic node)

$\circ$ axle arrangment

o type and variant of electric traction motors (direct current, asynchronous or synchronous)

○ number of motors and traction converters

$\circ$ type and variant of traction converters

o type and variant of brake systems (electrodynamic, rail, disc, jaw or eddy current brakes)

o the type of autonomous drive system (battery, capacitor storage or capacitor storage with battery),
W związku z tymi różnicami nie zawsze możliwe jest wyprodukowanie pojazdów, które mogłyby poruszać się po wszystkich torowiskach w kraju.

Jednak mimo różnic, pojazdy poruszające się po tych sieciach podlegają tym samym wymaganiom prawnym. Przepisy regulujące homologację tramwajów w Polsce zostały wydane na podstawie Ustawy z dnia 20 czerwca 1997 roku Prawo o ruchu drogowym, a są nimi:

- Rozporządzenie Ministra Transportu i Gospodarki Morskiej z dnia 28 maja 2013 r. w sprawie homologacji typu tramwajów i trolejbusów (Dz. U. 2015 r. poz. 38).

- Rozporządzenie Ministra Infrastruktury z dnia 2 marca 2011 r. w sprawie warunków technicznych tramwajów i trolejbusów oraz zakresu ich niezbędnego wyposażenia (Dz. U. 2011 r. nr 65 Poz. 344)

Dokumentem potwierdzającym spełnienie przez typ tramwaju ww. wymagań jest świadectwo homologacji typu pojazdu. W ramach wydanego świadectwa określono istotne cechy różnicujące typ, wariant lub wersję tramwaju i przedstawiono je następująco:

- typ - obejmuje pojazdy, dla których wspólne są wszystkie, następujące cechy:

$\circ$ producent

○ fabryczne oznaczenie typu

○ główne względy konstrukcyjne, w tym:

- konstrukcja pudła (oczywiste i podstawowe różnice)

- główny napęd trakcyjny (elektryczny sieciowy lub elektryczny autonomiczny)

- liczba członów tramwaju

- wariant - w ramach typu pojazdu obejmuje pojazdy, dla których wspólne są wszystkie, następujące cechy konstrukcyjne:

o rodzaj tramwaju (silnikowy, doczepny czynny, doczepny bierny)

o kierunkowość tramwaju (jednokierunkowy lub dwukierunkowy)

○ nominalne napięcie zasilania

o szerokość toru

○ wózki lub podwozie (istotne cechy konstrukcyjne)

○ osie napędzane (liczba, położenie, powiązanie kinematyczne)

○ układ osi

○ typ i rodzaj silników trakcyjnych elektrycznych (prądu stałego, asynchroniczny albo synchroniczny)

- liczba silników i przekształtników trakcyjnych

○ typ i rodzaj przekształtników trakcyjnych

○ typ i rodzaj układów hamulcowych (elektrodynamiczne, szynowe, tarczowe, szczękowe lub zwalniacze wiroprądowe) 
- version - for a given variant, it includes vehicles for which all of the following features are common:

○ maximum permitted vehicle mass

○ nominal power of the traction drive

○ maximum number of seats

0 transmission type and variant

$\circ$ the type and variant of devices operating at traction voltage, in particular pantographs, and overcurrent relase protection

o the type and variant of basic auxiliary equipment (converters, heating, auxiliary drives motor)

o the placement location of traction converters, traction motors, inverters, auxiliary motors and elements of the autonomous drive system

0 the additional autonomous drive power.

2. TRAM TYPE APPROVAL PROCESS - TYPE APPROVAL TESTS, PRODUCTION COMPLIANCE CONTROL AND INTRODUCTION OF CHANGES

Tram type approval process in Poland can only be performed by an authorized legal entity, such as the Rail Vehicles Institute "TABOR" in Poznań. The process itself has been divided into two parts:

- Type approval tests

- Production compliance control

Type approval consists of a technical test and is carried out for the purpose of determining whether the vehicle type meets the technical requirements set out in the provisions listed in paragraph 1 of this article.

The production compliance control is carried out to confirm the manufacturer's ability to ensure the appropriate reproducibility of the production process, so as to ensure that the subsequent vehicles comply with the approved/requested type approval of the vehicle.

The process ends with the submission of the application by the manufacturer to the Transport Technical Supervision for the issue of the Vehicle Type Approval Certificate.

\subsection{TYPE APPROVAL TESTS}

The type approval process consists of a series of tests, measurements and checks both on the vehicle itself as well as analyzing and verifying its documentation.

The documentation verification includes:

- document informing about the tram type approval purpose

- technical and operational documentation of the tram, which also includes wear limit values for individual elements

- tram operation manual

- instructions for lifting and inserting a tram into a track
○ rodzaj układu jazdy autonomicznej (akumulatorowy, zasobnik kondensatorowy albo zasobnik kondensatorowy z baterią akumulatorów),

- wersja - w ramach wariantu obejmuje pojazdy, dla których wspólne są wszystkie następujące cechy:

o dopuszczalna masa całkowita

- nominalna moc napędu trakcyjnego

o największa liczba miejsc siedzących

○ typ i rodzaj przekładni

○ typ i rodzaj urządzeń pracujących pod napięciem trakcyjnym, w szczególności odbieraki prądu, urządzenia zabezpieczeń nadmiarowych obwodów sieciowych

○ typ i rodzaj podstawowych urządzeń pomocniczych (przetwornice, ogrzewanie, silniki napędów pomocniczych)

- miejsce zainstalowania przekształtników trakcyjnych, silników trakcyjnych, przetwornic, silników pomocniczych, elementów układu napędu autonomicznego

○ moc dodatkowego napędu autonomicznego.

\section{PROCES HOMOLOGACJI TRAMWAJÓW - BADANIA HOMOLOGACYJNE I KONTRO- LA ZGODNOŚCI PRODUKCJI ORAZ WPROWADZANIE ZMIAN}

Proces homologacji tramwajów może zostać przeprowadzony tylko i wyłącznie przez jednostkę uprawnioną, jaką w Polsce jest m. in. Instytut Pojazdów Szynowych „TABOR” w Poznaniu. Sam proces został podzielony na dwie części:

- badania homologacyjne

- kontrolę zgodności produkcji.

Badanie homologacyjne jest badaniem technicznym i przeprowadzane jest na potrzeby stwierdzenia, czy dany typ pojazdu spełnia wymagania techniczne określone $\mathrm{w}$ przepisach wymienionych w punkcie 1 niniejszego artykułu.

Kontrola zgodności produkcji przeprowadzana jest w celu potwierdzenia zdolności producenta do przeprowadzenia $\mathrm{z}$ odpowiednią powtarzalnością procesu produkcyjnego, tak aby w ten sposób zapewnić zgodność kolejnych egzemplarzy danego pojazdu z zatwierdzonym/wnioskowanym o zatwierdzenia typem pojazdu.

Proces kończy się złożeniem przez producenta wniosku do Transportowego Dozoru Technicznego o wydanie Świadectwa homologacji typu pojazdu.

\subsection{BADANIA HOMOLOGACYJNE}

Badanie homologacyjne polega na wykonaniu szeregu prób, badań i sprawdzeń, zarówno samego pojazdu, jak i sprawdzeniu i analizie jego dokumentacji.

Sprawdzeniu na podstawie samej dokumentacji podlegają: 
- certificates confirming fire safety for compliance with the PN-K-02511:2000 standard for non-metallic materials used in the interior of the tram

- certificates confirming the electric cables used in the vehicle interior are made of halogen-free materials

- calculation of the kinematic gauge of the tram

- type approval certificates for external lights used

- type approval certificates for the glass elements used

- diagrams of protection connection between the electric mass of the tram body and the rail

- description of the deadman system operation

- description of the driving lock system operation

- description of the door mechanisms operation and the safety systems against passengers getting caught in the door mechanism

- protocols for testing the insulation strength of electrical subassemblies done by the manufacturers of these components

- documents confirming the manufacturer's ability to ensure the production of more trams in accordance with the type approved

- resistance measurement results and dielectric insulation testing of cabling used

- resistance measurement results and dielectric insulation strength tests of the apparatus.

Technical verification, however, includes the following tests:

- stationary tests and tram test drive

- tests of wheel sets pressure

- tests of the railway vehicles acoustic properties

- tram lighting tests

- testing of tram braking systems

- testing of the tram's electric system

- electrical interference tests.

The detailed scope of the above technical tests includes the following elements:

- external tram dimensions measurement

- measurement of static pressures exerted on the track by individual axles of a fully loaded tram

- measurement of the sound level emitted outside the tram when stationary

- measurement of the sound level emitted outside the tram when driving

- measurement of the sound level of the warning signal

- measuring the lighting intensity inside the tram, and in front and behind areaof the door

- measurement of braking distance from $30 \mathrm{~km} / \mathrm{h}$ for service, emergency and safety brakes

- parking brake effectiveness check
- dokument informacyjny do celu homologacji typu tramwaju

- dokumentacja techniczno-ruchowa tramwaju, zawierająca również graniczne wielkości zużycia poszczególnych elementów

- instrukcja obsługi tramwaju

- instrukcja podnoszenia i wstawiania tramwaju w tor

- świadectwa potwierdzające bezpieczeństwo przeciwpożarowe na zgodność z normą PN-K02511:2000 dla materiałów niemetalowych użytych we wnętrzu tramwaju

- świadectwa potwierdzające wykonanie przewodów elektrycznych we wnętrzu z materiałów wolnych od halogenów

- obliczenia skrajni kinematycznej tramwaju

- świadectwa homologacji dla zastosowanych świateł zewnętrznych

- świadectwa homologacji zastosowanego oszklenia

- schematy połączeń ochronnych pomiędzy masą elektryczną nadwozia tramwaju a szyną

- opis działania układu czuwaka

- opis działania układu blokady jazdy

- opis działania mechanizmów drzwiowych i zastosowanych zabezpieczeń przed przytrzaśnięciem pasażera

- protokoły z prób wytrzymałości izolacji podzespołów elektrycznych przeprowadzanych przez producentów tych podzespołów

- dokumenty potwierdzających zdolność producenta do zapewnienia wytwarzania kolejnych tramwajów zgodnych z typem homologowanym

- wyniki pomiarów rezystancji i testów wytrzymałości izolacji dielektrycznej okablowania

- wyniki pomiarów rezystancji i testów wytrzymałości izolacji dielektrycznej aparatury.

Badania techniczne natomiast obejmują wykonanie następujących testów:

- badania stacjonarne i jazda próbna tramwaju

- badania nacisków zestawów kołowych

- badania właściwości akustycznych pojazdów szynowych

- badania oświetlenia tramwaju

- badania układów hamulcowych tramwaju

- badania układu elektrycznego tramwaju

- badania zakłóceń elektrycznych.

Szczegółowy zakres powyższych badań technicznych zawiera następujące elementy:

- pomiar wymiarów zewnętrznych tramwaju

- pomiar nacisków statycznych wywieranych na tor przez poszczególne osie $\mathrm{w}$ pełni obciążonego tramwaju

- pomiar poziomu dźwięku emitowanego na zewnątrz tramwaju na postoju 
- checking the emergency braking systems of each detachable tram memberin case of detachment of the tram member from the member

- checking the functionality and operation of the reverse drive maneuvering console, if applicable

- checking the brakes operation for back driving

- checking the ability to activate at least the emergency and parking brake, independently electronic controller

- checking devices that improve the coefficient of friction between the wheel and the rail

- testing the location of external lights on the tram

- checking the external lights, their operation, electrical connections and controls lights

- testing the train stopping mechanism for open door

- checking the correct deadman operation

- testing the possibilityof back drive

- checking the electrical protection system from being accessed by passengers and bystanders

- checking the electrical protection system from mechanical damage, corrosion and flooding

- checking access to the low voltage electrical circuit breaker

- checking if the electrical installation is equipped with a protection against short circuit

- checking the tram brakes operation in the case of a catenary accident

- checking the safety connections between the electric mass of the tram body and the rail and measuring the resistance of these connections

- checking the connections of the electrical masses of the individual components in multiple trams and the correct connection of electric masses of tram compartments that are to operate together

- measurement of the resistance between exposed elements made of conductive materials in the tram interior and the safety ground or the tram body

- checking the operation of electrical installations with capacitive elements or other energy sources and trams equipped with an autonomous driving systems

- voltage measurement on the supply side (on the pantograph) in a real drive on the municipal network - for trams adapted to generation thebraking energy to the catenary

- tram test drive

- checking the required tram equipment

- on trams expected to operate with additional compartments - checking the coupling cover

- checking the driver's seat equipment

- checking the passenger compartment equipment
- pomiar poziomu dźwięku emitowanego na zewnątrz tramwaju w ruchu

- pomiar poziomu dźwięku sygnału ostrzegawczego

- pomiar natężenia oświetlenia wewnątrz tramwaju, w przestrzeni przed i za drzwiami

- pomiar długości drogi hamowania z prędkości $30 \mathrm{~km} / \mathrm{h}$ dla hamulców: roboczego, nagłego, awaryjnego i bezpieczeństwa

- próbę skuteczności działania hamulca postojowego

- sprawdzenie w tramwaju doczepnym układu włączającego hamulce w przypadku odłączenia się tego tramwaju od składu

- sprawdzenie funkcjonalności i działania pulpitu manewrowego do jazdy do tyłu, o ile dotyczy

- sprawdzenie działania hamulców przy jeździe do tyłu

- sprawdzenie możliwości uruchomienia przynajmniej hamulca awaryjnego i postojowego, niezależnie od sterownika elektronicznego

- sprawdzenie wyposażenia w urządzenie poprawiające współczynnik przyczepności między kołem i szyną

- pomiar rozmieszczenia świateł zewnętrznych na tramwaju

- sprawdzenie wyposażenia w światła zewnętrzne, ich działania, połączeń elektrycznych oraz kontrolek

- sprawdzenie działania blokady ruszenia z otwartymi drzwiami

- sprawdzenie działania czuwaka

- sprawdzenie możliwości jazdy do tyłu

- sprawdzenie zabezpieczenia instalacji elektrycznej przed dostępem pasażerów i osób postronnych

- sprawdzenie zabezpieczenia instalacji elektrycznej przed uszkodzeniami mechanicznymi, korozją i zalaniem

- sprawdzenie dostępu do wyłącznika instalacji elektrycznej niskiego napięcia

- sprawdzenie wyposażenia instalacji elektrycznej w zabezpieczenie w razie wystapienia zwarcia

- sprawdzenie działania hamulców w awaryjnych stanach pracy sieci trakcyjnej

- sprawdzenie połączeń ochronnych pomiędzy masą elektryczną nadwozia tramwaju a szyną oraz pomiar rezystancji tych połączeń

- sprawdzenie połączeń mas elektrycznych pudeł poszczególnych członów w tramwajach wieloczłonowych oraz możliwości połączenia mas elektrycznych tramwajów przewidzianych do pracy w układzie wielokrotnym

- pomiar rezystancji między odsłoniętymi elementami wykonanymi z materiałów przewodzących 
- check the stairs marking

- checking the number of doors, their location, measurement of the length of the passenger space when half-closed, measuring the width of the passage, checking the required number of passenger

- checking the adaptation of at least one door to the needs of persons with reduced mobility (prm)

- checking passenger safety systems operation in the entrance door, the mechanical opening and closing, emergency opening, individual opening, buttons for the disabled, warning signal

- measuring the force needed for emergency opening of the doors

- measurement of the force needed to move the lever mechanism activating the emergency brakes

- measurement of the force exerted on a passenger trapped in the closing door

- checking how the windows are opened, and checking the proper quality of front and rear windows

- checking the markings on glass windows

- measurement of the windscreens light transmitance coefficient

- checking the state, number and marking of emergency exits and checking the remote access control of them using the appropriate marking

- checking the arrangement of handrails and handles with an appropriate pattern

- measurement of the floor gaps dimensions in coupler area

- checking the cover in the coupling area

- measurement of electromagnetic disorders emitted to the environment

- checking, after the test, that there are no consumables are leaking.

After performing the activities listed above, a report on type approval tests is prepared, part of which is a report on the tests carried out (including the technical tests results) and the results of the documentation analysis.

\subsection{PRODUCTION COMPLIANCE CONTROL}

The second part of the process is production compliance control. It is carried out in order to confirm the manufacturer's ability to prove the appropriate reproducibility of the production process, so as to ensure compliance of subsequent copies of the vehicle with the approved/requested type approval of the vehicle. Production compliance control is divided into two steps:

- initial assessment

- verification of projects and methods ensuring we wnętrzu tramwaju a konstrukcją tramwaju

- sprawdzenie działania uzależnień w tramwajach z instalacją elektryczną z elementami pojemnościowymi lub innymi źródłami energii oraz $\mathrm{w}$ tramwajach wyposażonych $\mathrm{w}$ układ jazdy autonomicznej

- pomiar napięcia po stronie zasilania (na odbieraku) w czasie rzeczywistej jazdy po sieci miejskiej - dla tramwajów przystosowanych do zwrotu energii do sieci trakcyjnej

- jazdę próbną

- sprawdzenie wymaganego wyposażenia tramwaju

- w tramwajach przewidzianych do pracy w zespołach - sprawdzenie osłony sprzęgów międzywagonowych

- sprawdzenie wyposażenia stanowiska motorniczego

- sprawdzenie wyposażenia przedziału pasażerskiego

- sprawdzenie oznakowania krawędzi stopni

- sprawdzenie liczby drzwi, ich rozmieszczenia, pomiar długości przestrzeni pasażerskiej jednostronnie zamkniętej, pomiar szerokości przejścia, sprawdzenie wymaganej liczby strumieni wymiany pasażerów

- sprawdzenie przystosowania przynajmniej jednych drzwi do potrzeb osób niepełnosprawnych

- sprawdzenie w drzwiach wejściowych działania systemów zabezpieczających przed przytrzaśnięciem pasażera, mechanicznego otwierania i zamykania, awaryjnego otwierania, indywidualnego otwierania, przycisków dla niepełnosprawnych, sygnału ostrzegawczego

- pomiar siły potrzebnej do awaryjnego otwarcia drzwi

- pomiar siły potrzebnej do uruchomienia mechanizmu dźwigniowego włączającego hamulce bezpieczeństwa

- pomiar siły przytrzaśnięcia pasażera $\mathrm{w}$ drzwiach

- sprawdzenie sposobu otwierania okien oraz wykonania okien przednich i tylnych

- sprawdzenie ocechowania szyb

- pomiar współczynnika przepuszczalności światła w szybach przednich

- sprawdzenie wykonania, liczby i sposobu oznakowania wyjść awaryjnych oraz kontrola dostępu do nich za pomocą odpowiednich oznakowań

- kontrola rozmieszczenia poręczy i uchwytów za pomoca odpowiedniego sprawdzianu

\subsection{KONTROLA ZGODNOŚCI PRODUKCJI}

Drugą częścią procesu jest kontrola zgodności produkcji. Przeprowadzana jest ona $\mathrm{w}$ celu potwierdzenia zdolności producenta do przeprowadzenia $\mathrm{z}$ odpowiednią powtarzalnością procesu produkcyjnego, tak aby w ten sposób zapewnić zgodność kolejnych 
vehicles, equipment or parts production compliance, hereinafter referred to as products, with the type covered by the type approval certificate.

As part of the initial assessment, the existence of a production compliance management system of the manufacturer is checked, including:

- the manufacturer's documentation confirming compliance with the harmonized ISO 9001 standard or with an equivalent harmonized standard that meets the general requirements of the initial assessment

- documentation of the vehicle manufacturer within the scope of the quality management system assessment performed by the manufacturer of the equipment or parts, in accordance with at least one industrial specification meeting the requirements of the abovementioned standards.

As part of the verification of manufacturer's projects andmethods and procedures used to ensure the compliance of manufactured products with the type covered by the type approval certificate, the following aspects are verified:

- the method of the production process functioning, specifically:

$\circ$ production planning

$\circ$ keeping and storing the production documentation

- supervising individual stages of the production process

- storage and transport of finished products

- the method of product delivery system operation, specifically:

o the existence of a supplier evaluation system

- storage and control of delivered goods

$\circ$ the use of product markings for efficient and timely delivery

- procedures for product complaints

- the presence of an examine and internal controls system for the manufactured products, in particular ensuring:

- checking the completeness of vehicle conformity with the data contained in the type-approval certificate

- access to research and development and control equipment, including identification and testing this equipment

- documenting and sharing the results of products tests and internal controls, among others through control plans

- conducting the analysis of tests and internal controls results in terms of the manufacturer checking and ensuring that the manufactured product remains in the same quality range, while taking into account the progress in manufacturing technology and industrial production egzemplarzy danego pojazdu $\mathrm{z}$ zatwierdzonym/wnioskowanym o zatwierdzenia typem pojazdu Kontrola zgodności produkcji składa się z dwóch etapów:

- oceny wstępnej

- weryfikacji przedsięwzięć i metod zapewniających zgodność produkcji pojazdów, przedmiotów wyposażenia lub części, zwanych dalej wyrobami, $\mathrm{z}$ typem objętym świadectwem homologacji.

$\mathrm{W}$ ramach oceny wstępnej sprawdzane jest istnienie u producenta systemu zarządzania jakością, uwzględniające:

- dokumentację producenta potwierdzającą zgodność ze zharmonizowana normą ISO $9001 \mathrm{lub}$ z równoważną zharmonizowaną norma, która spełnia ogólne wymagania oceny wstępnej

- dokumentację producenta pojazdu w zakresie przeprowadzonej przez niego oceny systemu zarządzania jakością u producenta przedmiotów wyposażenia lub części, zgodnie co najmniej z jedną specyfikacją przemysłową, spełniająca wymagania ww. normy

W ramach weryfikacji wprowadzonych przez producenta przedsięwzięć i metod zapewniających zgodność produkcji wyrobów z typem objętym świadectwem homologacji sprawdza się:

- sposób funkcjonowania procesu produkcyjnego wyrobów, w szczególności:

o planowanie produkcji

○ prowadzenie i przechowywanie dokumentacji produkcyjnej

○ nadzorowanie poszczególnych etapów procesu produkcyjnego

$\circ$ przechowywanie i transport wyrobów gotowych

- sposób działania systemu dostawy wyrobów, w szczególności:

○ istnienie systemu oceny dostawców

- magazynowanie i kontrolę dostaw

- stosowanie oznaczeń wyrobów na potrzeby skutecznej i terminowej dostawy

○ procedury reklamacji wyrobów

- istnienie systemu badań i kontroli wewnętrznych produkowanych wyrobów, w szczególności zapewnienie:

- sprawdzenia zgodności kompletacji pojazdu z danymi zawartymi w świadectwie homologacji typu

○ dostępu do wyposażenia badawczorozwojowego i kontrolnego, w tym sposób identyfikacji i sprawdzania tego wyposażenia

- dokumentowania i udostępniania wyników badań i kontroli wewnętrznych wyrobów, między innymi poprzez plany kontroli 
o the effective process of eliminating discrepancies identified as a result of tests and internal controls

o the effective process of eliminating and withdrawing defective products from production, including the proper marking of such products.

The production compliance control process is summarized by the Production Compliance Control Protocol.

\subsection{INTRODUCING CHANGES}

The Regulation of the Minister of Transport and Maritime Economy of May 28, 2013 regarding type approval of trams and trolleybuses (Journal of Laws 2015 , item 8 ) provides the possibility of introducing modifications to the types of trams that have a valid type approval certificate. However, the description of the changes alone was not specified in detail. The legislator in the abovementioned regulation was limited only to the entries regarding:

- applycation for changing the type-approval certificate

- information document - "in the information document, the changes made are clearly indicated in bold font in the case of an application for a type-approval certificate modification, where this change requires new type-approval tests".

In relation to the above, it seems reasonable to use the experience of the railway market in Poland in the field of modernization and modification of railway vehicles using the risk management process.

\section{A PROPOSAL FOR USING EXPERIENCE GAINED FROM THE RAILWAY VEHI- CLES MARKET TO THE ISSUE OF TRAM MODERNIZATION}

This chapter presents the current general method of introducing modifications to railway vehicles (in structural subsystems) that can be used in the process of tram type approval. In cases of modernization of the structural subsystem, the entity offering the modification provides the President of UTK with documentation describing the project along with an assessment of the significance of the change (performed in accordance with the European Commission regulations regarding a common safety assessment method for risk evaluation and assessment).

The guidelines on common safety methods (CSM) used for rail transport appeared for the first time in Directive 2004/49/EC, defining both CSMs and common safety requirements called CST (Common Safety Targets).

The need to carry out safety assessments in the scope of risk evaluation and assessment by the manufacturers and railway operators was imposed by Regulation No. 352/2009, which was later replaced by the current
- prowadzenia analizy wyników badań i kontroli wewnętrznych pod kątem sprawdzania i zapewnienia przez producenta zachowania na takim samym poziomie produkcji wyrobów, z jednoczesnym uwzględnianiem postępu $\mathrm{w}$ obszarze technicznym i produkcji przemysłowej

- skutecznego procesu eliminowania niezgodności stwierdzonych w wyniku badań i kontroli wewnętrznych

- skutecznego procesu eliminowania i wycofywania z produkcji wyrobów wadliwych, w tym stosowania oznaczeń takich wyrobów.

Proces kontroli zgodności produkcji podsumowywany jest Protokołem kontroli zgodności produkcji.

\subsection{WPROWADZANIE ZMIAN}

Rozporządzenie Ministra Transportu i Gospodarki Morskiej z dnia 28 maja 2013 r. w sprawie homologacji typu tramwajów i trolejbusów (Dz. U. 2015 r. poz. 8) przewiduje możliwość wprowadzania modyfikacji w typach tramwajów posiadających aktualne świadectwo homologacji. Jednak sam opis wprowadzania zmian nie został określony szczegółowo. Ustawodawca w ww. rozporządzeniu ograniczył się jedynie do zapisów dotyczących:

- wniosku o zmianę świadectwa homologacji typu

- dokumentu informacyjnego - „W dokumencie informacyjnym wprowadzone zmiany są wyraźnie zaznaczone przez pogrubienie czcionki $\mathrm{w}$ przypadku wniosku o zmianę świadectwa homologacji typu, gdy zmiana ta wymaga przeprowadzenia nowych badań homologacyjnych".

W związku z powyższym zasadne wydaje się być skorzystanie $\mathrm{z}$ doświadczeń rynku kolejowego w Polsce $\mathrm{w}$ zakresie modernizacji i odnawiania pojazdów kolejowych przy zastosowaniu procesu zarządzania ryzykiem.

\section{PROPOZYCJA PODEJŚCIA DO ZAGAD- NIENIA MODERNIZACJI TRAMWAJÓW PRZY WYKORZYSTANIU DOŚWIADCZEŃ Z BRANŻY POJAZDÓW KOLEJOWYCH}

W niniejszym rozdziale przedstawiono aktualny ogólny sposób wprowadzania modyfikacji w pojazdach kolejowych (w podsystemach strukturalnych) możliwy do wykorzystania w procesie homologacji tramwajów. W przypadkach modernizacji podsystemu strukturalnego wprowadzający modyfikację przekazuje Prezesowi UTK dokumentację opisującą projekt wraz z oceną znaczenia wprowadzanej zmiany (przeprowadzoną zgodnie z przepisami Komisji Europejskiej dotyczącymi wspólnej metody oceny bezpieczeństwa w zakresie wyceny i oceny ryzyka).

Wytyczne na temat wspólnych metod oceny bezpieczeństwa wykorzystywanych transporcie kolejowym (ang. CSM - Common Safety Methods) po raz pierwszy pojawiły się w Dyrektywie 2004/49/WE, w której 
Regulation 402/2013, but is still referred to by national normative documents, including those concerning modernized and modified vehicles.

The scope of obligations on the part of the entity introducing changes is regulated by the Regulation of the Ministry of Infrastructure and Architecture on the interoperability of the railway system (Journal of Laws of 2017, item 934), which lists the necessary documents needed for obtaining autorization for placing vehicles in force that are compliant or incompliant with the Technical Interoperability Specifications. Based on the provisions of the abovementioned regulations works are carried out related to the entities trying to obtain permission to limit the scope of parameters necessary to inspect modernized railway vehicles.

Modification of the vehicle should be described by the proposing entity in the form of a safety assessment. Depending on the scope of introduced changes, one of the necessary elements may be a safety assessment report issued by the assessment body in cases specified in the European Union regulations regarding a common safety assessment method in the scope of risk evaluation and assessment.

It should be noted that, according to the recommendations, the decisions taken by the contracting entity or manufacturer regarding changes to the subsystem, which based on the four categories set out in Figure 1, must be completely independent of the decision regarding the significance of the change in terms of common safety assessment methods in the risk assessment and assessment for the railway system, and it is to be performed by the entity wishing to introduce the modification in its part of the system.

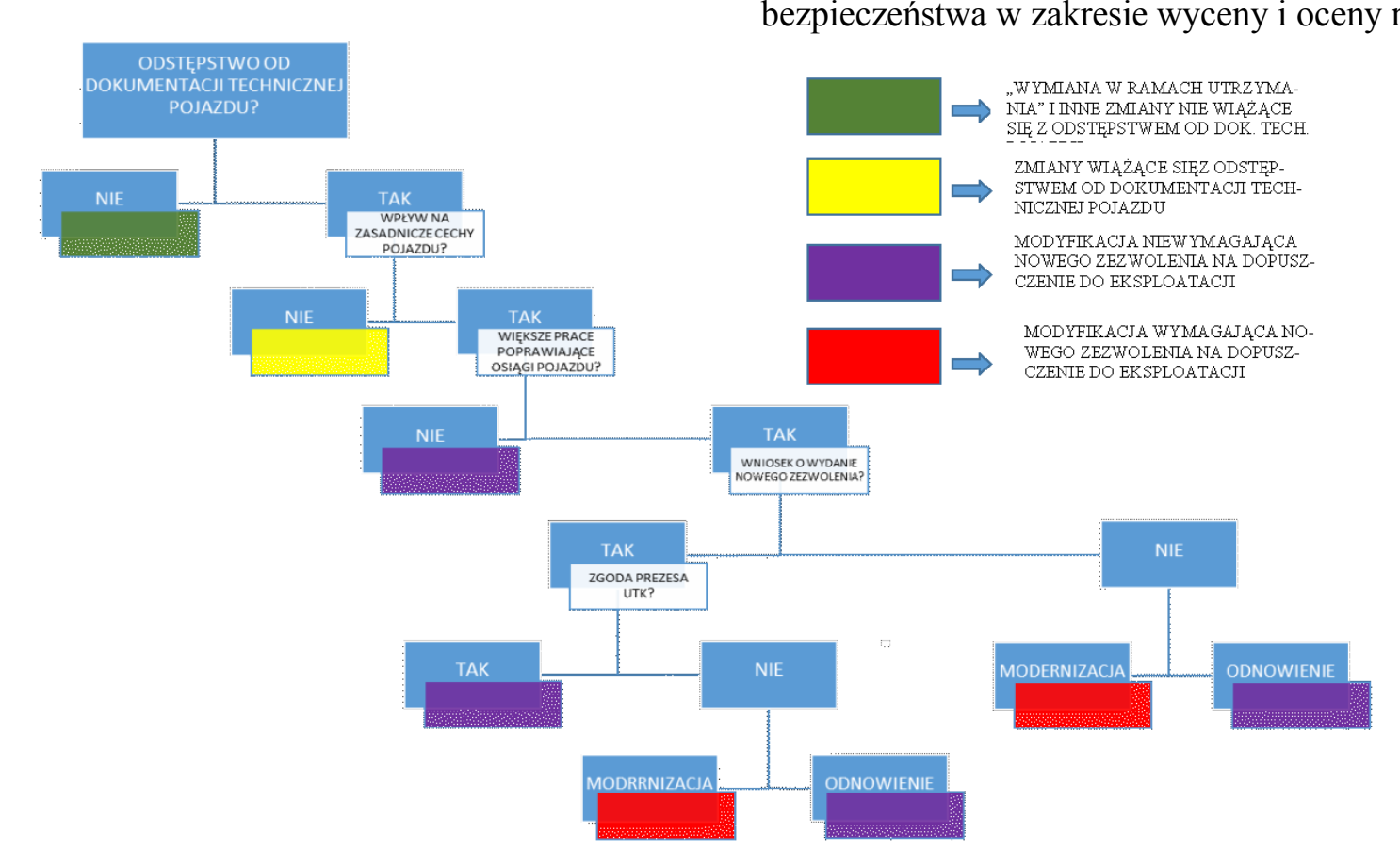

Fig. 1.Diagram describing the procedure of adding modifications in rail vehicles [original]

Rys. 1.Opis postępowania z modyfikacjami w pojazdach kolejowych [opracowanie własne] zdefiniowano zarówno CSM, jak i wspólne wymagania bezpieczeństwa (ang. CST - Common Safety Targets).

Konieczność przeprowadzania oceny bezpieczeństwa w zakresie wyceny i oceny ryzyka przez producentów i przewoźników kolejowych została narzucona wraz z wejściem w życie Rozporządzenia nr 352/2009, które zastapione przez aktualne Rozporządzenie 402/2013, przywoływane jest nadal przez krajowe dokumenty normatywne, w tym także dotyczące modernizowanych i odnawianych pojazdów kolejowych.

Zakres obowiązków leżących po stronie wprowadzającego zmiany regulowany jest przez Rozporządzenie MIiB w sprawie interoperacyjności systemu kolei (Dz. U. z 2017 r. poz. 934), w którym zestawiono niezbędne dokumenty do uzyskania zezwolenia na dopuszczenie do eksploatacji pojazdów zgodnych bądź niezgodnych z Technicznymi Specyfikacjami Interoperacyjności. W oparciu o zapisy ww. rozporządzenia wykonywane są także prace związane ze staraniem się przez podmioty ubiegające się o uzyskania zgody na możliwość ograniczenia zakresu parametrów koniecznych do skontrolowania modernizowanych pojazdów kolejowych.

Modyfikacja pojazdu powinna zostać opisana przez wprowadzającego zmiany za pomocą oceny bezpieczeństwa. W zależności od zakresu wprowadzonych zmian jednym $z$ elementów niezbędnych do przygotowania może być raport $z$ oceny bezpieczeństwa wydany przez jednostkę oceniająca w przypadkach określonych w przepisach Unii Europejskiej, dotyczących wspólnej metody oceny bezpieczeństwa w zakresie wyceny i oceny ryzyka. 


\section{Stages of risk assessment}

According to the definition provided in Regulation $402 / 2013$, risk assessment is a comprehensive process comprising the following stages:

- defining the system to be assessed

- risk analysis, including identification of hazards

- risk assessment.

In accordance with the Regulation 402/2013 (as amended), the risk management process is carried out in the event of a significant change, which is assessed with regard to six criteria: system failure consequences, innovation used in the introduced change, change complexity, monitoring, reversibility of change , additionality.

Performing a security assessment starts with defining the system being evaluated. In the event of a safety assessment for the needs of the contracting entity or the manufacturer to obtain an approval to limit the range of parameters required to be checked, changes are indicated between the modernized vehicles and the reference system in the form of a vehicle already approved for operation. However, when carrying out the safety assessment annexed to the EC verification declaration, a change is defined relative to the introduction of a new type of vehicle to the railway system. Regardless of the above reasons for performing the risk assessment, the system definition must take into account:

- system purpose (intended purpose)

- functions and elements of the system, if applicable (including human, technical and operational elements)

- the system boundary, taking into account other systems with which this system interacts, for example, infrastructure, energy, control, railway traffic, etc.

- physical interfaces (interfaces through which this system interacts with other systems) and functional (inputs and effects on operation)

- system environment (e.g. energy flows and thermal flows, shocks, vibrations, electromagnetic interference, exploitation destination, environmental conditions or entities responsible for maintenance)

- existing security measures and the definition of security requirements identified through the risk assessment process (on the next necessary stages)

- assumptions specifying the thresholds applicable to the risk assessment.

The next step in the risk assessment is that the entity performs a risk analysis, including hazard identification. All rationally predictable threats related to the entire system under evaluation are identified. All newly identified threats are entered into the hazard register, which should be updated after each analusis. After all hazards have been identified through a professional judgment of a competent team, the next
Należy zaznaczyć, iż zgodnie zaleceniami decyzje podjęte przez podmiot zamawiający lub producenta, dotyczące zmian podsystemu, które oparte na czterech kategoriach zestawionych na rys. 1, muszą być zupełnie niezależne od decyzji dotyczącej istotności danej zmiany, jeżeli chodzi o wspólne metody oceny bezpieczeństwa w zakresie wyceny i oceny ryzyka dla systemu kolejowego, która ma być dokonana przez przedsiębiorstwo kolejowe wprowadzające modyfikację w swojej części systemu.

\section{Etapy oceny ryzyka}

Zgodnie $\mathrm{z}$ definicją zawartą $w$ Rozporządzeniu 402/2013 ocena ryzyka jest całościowym procesem obejmującym następujące etapy:

- zdefiniowanie systemu podlegającego ocenie

- analizę ryzyka, w tym identyfikację zagrożeń

- wycenę ryzyka.

Zgodnie z Rozporządzeniem 402/2013 (z późn. zm.) konieczność przeprowadzenia procesu zarządzania ryzykiem zachodzi w przypadku zmiany znaczącej, która jest oceniana w odniesieniu do pięciu kryteriów: skutki awarii systemu, innowacja wykorzystana przy wprowadzeniu zmiany, złożoność zmiany, monitoring, odwracalność zmiany, dodatkowość.

Tworzenie oceny bezpieczeństwa rozpoczyna się od zdefiniowania systemu podlegającego ocenie. W przypadku wykonywania oceny bezpieczeństwa na potrzeby ubiegania się przez podmiot zamawiający lub producenta zgody o możliwość ograniczenia zakresu parametrów koniecznych do skontrolowania wskazywane są zmiany pomiędzy modernizowanymi pojazdami, a systemem odniesienia w postaci pojazdu już dopuszczonego do eksploatacji. Natomiast wykonując ocene bezpieczeństwa stanowiącą załącznik do deklaracji weryfikacji WE podsystemu, definiowana jest zmiana związana $\mathrm{z}$ wprowadzeniem nowego typu pojazdu do systemu kolejowego. Niezależnie od ww. powodów wykonywania oceny ryzyka, definicja systemu musi uwzględniać:

- cel systemu (zamierzone przeznaczenie)

- funkcje i elementy systemu, jeżeli ma to zastosowanie (w tym element ludzki, techniczny i operacyjny)

- granicę systemu, z uwzględnieniem innych systemów, z którymi system ten wzajemnie oddziałuje np. infrastruktura, energia, sterowanie, ruch kolejowy etc.

- interfejsy fizyczne (systemy, z którymi system ten wzajemnie oddziałuje) i funkcjonalne (nakłady i efekty dotyczące działania)

- otoczenie systemu (np. przepływy energii i przepływy termiczne, wstrząsy, wibracje, zakłócenia elektromagnetyczne, przeznaczenie eksploatacyjne, warunki środowiskowe lub podmioty odpowiedzialne za utrzymanie)

- istniejące środki bezpieczeństwa oraz definicja 
stage of risk assessment begins, employing one of the 3 methods described in Table 1. Risks resulting from hazards classified as generally acceptable (the criterion stating that the risk is small enough that introducing any additional security measures is unreasonable is met), they do not have to be analyzed further, but they should be placed in the hazard register.

Description of risk assessment methods based on Regulation 402/2013

Opis metod wyceny ryzyka wykonanej w oparciu o Rozporządzenie 402/2013

Table 1

Tablica 1

\begin{tabular}{|c|c|c|c|}
\hline & \multicolumn{3}{|c|}{ Risk assessment methods } \\
\hline & Code of conduct & Reference system & $\begin{array}{l}\text { Estimation and assessment of ex- } \\
\text { plicit risk }\end{array}$ \\
\hline 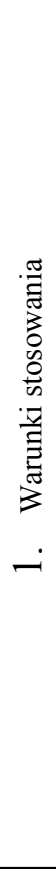 & $\begin{array}{l}\text { - they must be universally recog- } \\
\text { nized in the railway industry. } \\
\text { Otherwise, the codes of conduct } \\
\text { should be justified and they } \\
\text { should be acceptable to the as- } \\
\text { sessment body } \\
\text { - they must be significant from the } \\
\text { point of view of supervision over } \\
\text { the considered threats occurring } \\
\text { in the assessed system. Success- } \\
\text { ful application of a code of con- } \\
\text { duct for similar cases in relation } \\
\text { to change management and effec- } \\
\text { tive control of identified system } \\
\text { hazards within the meaning of } \\
\text { this Regulation is sufficient to } \\
\text { recognize them as significant } \\
\text { - they must be available to the } \\
\text { assessment bodies (inspection } \\
\text { bodies) at their request for the } \\
\text { purpose of their assessment or } \\
\text { mutual recognition, where ap- } \\
\text { propriate, of the risk management } \\
\text { process and its results. }\end{array}$ & $\begin{array}{l}\text { - has already been verified in } \\
\text { practice as a system with an ac- } \\
\text { ceptable level of safety and } \\
\text { would therefore also now meet } \\
\text { the conditions required for its ap- } \\
\text { proval in the Member State } \\
\text { where the change is to take place } \\
\text { - has similar functions and inter- } \\
\text { faces as the system being as- } \\
\text { sessed } \\
\text { - it is operated in similar condi- } \\
\text { tions of use as the system as- } \\
\text { sessed } \\
\text { it is operated in similar environ- } \\
\text { mental conditions as the system } \\
\text { being assessed. }\end{array}$ & $\begin{array}{l}\text { - applicable if the code of conduct } \\
\text { or reference system cannot be } \\
\text { used } \\
\text { - the methods used for explicit risk } \\
\text { estimation are correctly matched } \\
\text { to the system being assessed and } \\
\text { its parameters (including all work } \\
\text { modes) } \\
\text { - the results are sufficiently accu- } \\
\text { rate to serve as a plausible reason } \\
\text { for the decision. Small changes } \\
\text { in the input assumptions or pre- } \\
\text { conditions do not result in sig- } \\
\text { nificantly different results regard- } \\
\text { ing requirements. }\end{array}$ \\
\hline 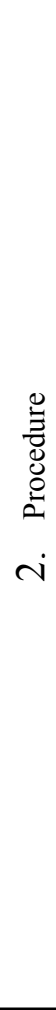 & $\begin{array}{l}\text { - If hazards are controlled by codes } \\
\text { of conduct that meet the above } \\
\text { requirements, the risks associated } \\
\text { with these hazards are considered } \\
\text { acceptable. This means that: } \\
\text { a) there is no need for a deeper } \\
\text { analysis of this risk } \\
\text { b) the use of codes of conduct is } \\
\text { recorded in the hazard record as a } \\
\text { safety requirement for the rele- } \\
\text { vant hazards. } \\
\text { - If the risk of a particular hazard } \\
\text { cannot be reduced to an accept- } \\
\text { able level by the use of a code of } \\
\text { conduct, additional security } \\
\text { measures should be defined using } \\
\text { one of the other two risk accep- } \\
\text { tance rules. }\end{array}$ & $\begin{array}{l}\text { - If the reference system meets the } \\
\text { requirements listed above, this } \\
\text { means that for the system under } \\
\text { evaluation: } \\
\text { a) the risks associated with haz- } \\
\text { ards included in the reference } \\
\text { system are considered accept- } \\
\text { able; } \\
\text { b) the safety requirements re- } \\
\text { garding hazards included in the } \\
\text { reference system may be derived } \\
\text { from safety analyzes or from the } \\
\text { assessment of safety records of } \\
\text { the reference system; } \\
\text { c) safety requirements thus de- } \\
\text { termined } \\
\text { If there are differences between } \\
\text { the assessed system and the ref- } \\
\text { erence system, the risk assess- } \\
\text { ment should demonstrate using } \\
\text { another reference system or one } \\
\text { of the other two risk acceptance } \\
\text { rules that the assessed system has } \\
\text { at least the same level of safety } \\
\text { as the reference system. In this } \\
\text { case, the risk associated with the } \\
\text { hazards included in the reference } \\
\text { system is considered acceptable. }\end{array}$ & $\begin{array}{l}\text { - Where hazards are not covered } \\
\text { by the code of conduct or the ref- } \\
\text { erence system, the acceptability } \\
\text { of risk is demonstrated by ex- } \\
\text { plicit risk estimation and assess- } \\
\text { ment. Risks resulting from these } \\
\text { threats should be assessed quali- } \\
\text { tatively or quantitatively (as de- } \\
\text { scribed in chapter 3.3.), Taking } \\
\text { into account the existing security } \\
\text { measures. }\end{array}$ \\
\hline
\end{tabular}




\begin{tabular}{|c|c|c|c|}
\hline & \multicolumn{3}{|c|}{ Metody wyceny ryzyka } \\
\hline & Kodeks postępowania & System odniesienia & $\begin{array}{c}\text { Szacowanie i wycena jawnego } \\
\text { ryzyka }\end{array}$ \\
\hline 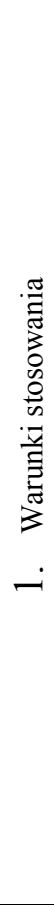 & $\begin{array}{l}\text { - muszą być powszechnie uznane } \\
\text { w branży kolejowej. W przeciw- } \\
\text { nym wypadku kodeksy postępo- } \\
\text { wania należy uzasadnić i powin- } \\
\text { ny one być akceptowalne dla } \\
\text { jednostki oceniającej } \\
\text { - muszą być istotne z punktu wi- } \\
\text { dzenia nadzoru nad rozważanymi } \\
\text { zagrożeniami występującymi w } \\
\text { ocenianym systemie. Udane za- } \\
\text { stosowanie kodeksu postępowa- } \\
\text { nia dla podobnych przypadków } \\
\text { w odniesieniu do zarządzania } \\
\text { zmianami i skutecznej kontroli } \\
\text { zidentyfikowanych zagrożeń sys- } \\
\text { temu w rozumieniu niniejszego } \\
\text { rozporządzenia jest wystarczaja- } \\
\text { ce do uznania ich za istotne } \\
\text { - muszą być dostępne dla organów } \\
\text { oceny (jednostki inspekcyjnej) na } \\
\text { ich żądanie w celu ich oceny lub, } \\
\text { w stosownych przypadkach, wza- } \\
\text { jemnego uznania, odpowiedniego } \\
\text { stosowania procesu zarządzania } \\
\text { ryzykiem oraz jego rezultatów. }\end{array}$ & $\begin{array}{l}\text { - sprawdził się już w praktyce jako } \\
\text { system o dopuszczalnym pozio- } \\
\text { mie bezpieczeństwa i dlatego } \\
\text { również obecnie spełniłby wa- } \\
\text { runki wymagane do jego za- } \\
\text { twierdzenia w państwie człon- } \\
\text { kowskim, w którym ma być } \\
\text { wprowadzona zmiana } \\
\text { - ma podobne funkcje i interfejsy } \\
\text { jak oceniany system } \\
\text { - jest eksploatowany w podobnych } \\
\text { warunkach eksploatacji jak oce- } \\
\text { niany system } \\
\text { - jest eksploatowany w podobnych } \\
\text { warunkach środowiskowych jak } \\
\text { oceniany system. }\end{array}$ & $\begin{array}{l}\text { - stosowane w przypadku braku } \\
\text { możliwości zastosowania kodek- } \\
\text { su postępowania bądź systemu } \\
\text { odniesienia } \\
\text { - metody stosowane do celów } \\
\text { szacowania jawnego ryzyka są } \\
\text { prawidłowo dobrane do ocenia- } \\
\text { nego systemu i jego parametrów } \\
\text { (w tym wszystkich trybów pracy) } \\
\text { - wyniki są dostatecznie dokładne, } \\
\text { aby mogły służyć jako wiary- } \\
\text { godne uzasadnienie decyzji. } \\
\text { Niewielkie zmiany w założeniach } \\
\text { wejściowych lub warunkach } \\
\text { wstępnych nie powodują znaczą- } \\
\text { co odmiennych wyników doty- } \\
\text { czących wymogów. }\end{array}$ \\
\hline 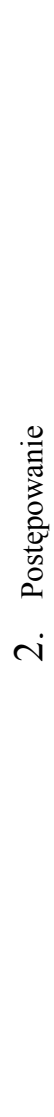 & $\begin{array}{l}\text { - Jeżeli zagrożenie lub zagrożenia } \\
\text { są kontrolowane za pomoca ko- } \\
\text { deksów postępowania spełniaja-- } \\
\text { cych powyższe wymogi ryzyko } \\
\text { związane z tymi zagrożeniami } \\
\text { uważa się za dopuszczalne. } \\
\text { Oznacza to, że: } \\
\text { a) nie istnieje potrzeba głębszego } \\
\text { analizowania tego ryzyka } \\
\text { b) stosowanie kodeksów postę- } \\
\text { powania zostaje odnotowane w } \\
\text { rejestrze zagrożeń jako wymóg } \\
\text { bezpieczeństwa w odniesieniu do } \\
\text { odpowiednich zagrożeń. } \\
\text { - Jeżeli ryzyko dotyczace określo- } \\
\text { nego zagrożenia nie może zostać } \\
\text { zredukowane do dopuszczalnego } \\
\text { poziomu przez zastosowanie ko- } \\
\text { deksu postępowania, należy } \\
\text { określić dodatkowe środki bez- } \\
\text { pieczeństwa za pomocą jednej z } \\
\text { dwóch pozostałych zasad akcep- } \\
\text { tacji ryzyka. }\end{array}$ & $\begin{array}{l}\text { - Jeżeli system odniesienia spełnia } \\
\text { wymogi wymienione powyżej, } \\
\text { oznacza to, że w przypadku oce- } \\
\text { nianego systemu: } \\
\text { a) ryzyko związane } \\
\text { z zagrożeniami uwzględnionymi } \\
\text { w systemie odniesienia uważa się } \\
\text { za dopuszczalne; } \\
\text { b) wymogi bezpieczeństwa doty- } \\
\text { czące zagrożeń uwzględnionych } \\
\text { w systemie odniesienia można } \\
\text { wywieść z analiz dotyczących } \\
\text { bezpieczeństwa lub z oceny zapi- } \\
\text { sów dotyczących bezpieczeństwa } \\
\text { systemu odniesienia; } \\
\text { c) określone w ten sposób wy- } \\
\text { mogi bezpieczeństwa } \\
\text { - Jeżeli występują różnice pomię- } \\
\text { dzy ocenianym systemem a sys- } \\
\text { temem odniesienia, wycena ry- } \\
\text { zyka powinna wykazać za pomo- } \\
\text { cą innego systemu odniesienia } \\
\text { lub jednej z dwóch pozostałych } \\
\text { zasad akceptacji ryzyka, że oce- } \\
\text { niany system cechuje co najmniej } \\
\text { taki sam poziom bezpieczeństwa } \\
\text { jak system odniesienia. W takim } \\
\text { przypadku ryzyko zwiazane } \\
\text { z zagrożeniami uwzględnionymi } \\
\text { w systemie odniesienia uważa się } \\
\text { za dopuszczalne. }\end{array}$ & $\begin{array}{l}\text { - W przypadku gdy zagrożenia nie } \\
\text { są objęte kodeksem postępowa- } \\
\text { nia ani systemem odniesienia, } \\
\text { dopuszczalność ryzyka jest udo- } \\
\text { wadniana za pomocą szacowania } \\
\text { i wyceny jawnego ryzyka. Ryzy- } \\
\text { ka wynikające z tych zagrożen } \\
\text { powinny być szacowane jako- } \\
\text { ściowo lub ilościowo (co zostało } \\
\text { opisane w rozdziale 3.3.), z } \\
\text { uwzglę-dnieniem istniejących } \\
\text { środków bezpieczeństwa. }\end{array}$ \\
\hline
\end{tabular}

The presented stages of risk assessment are also collected and presented in the form of a block diagram in addition to Regulation 402/2013 "Risk management process and independent evaluation".

The Institute of Rail Vehicles "TABOR" work experience indicates that the most commonly used method
Kolejnym etapem oceny bezpieczeństwa jest przeprowadzenie przez podmiot analizy ryzyka, w tym identyfikacji zagrożeń. Identyfikowane są wszystkie racjonalnie przewidywalne zagrożenia dotyczace całego ocenianego systemu. Wszystkie nowo wskazane zagrożenia zostają wpisane do rejestru zagrożeń, który 
of risk acceptance, concerning both new systems as well as modified or modernized vehicles, is the estimation and assessment of overt risk. The conditions necessary to comply with the proper use of this method are described in Table 1. After selecting the explicit risk evaluation method, the contracting entity or the vehicle manufacturer faces the challenge of choosing its specific method. Regulation 402/2013 does not impose on the contracting entity or the manufacturer of a modernized or modified rail vehicle the choice of the method of explicit risk estimation and assessment. It is supposed to be a method correctly selected for the system being evaluated and its parameters (including all modes of operation). Therefore, a few methods are described below that have or could apply to the assessment of an explicit risk.

The array method is a matrix method based on two risk parameters: the severity of consequences (effects) of hazards occurring at the workplace and the probability with which these consequences may occur. Estimating both the severity of the consequences and the probability of their occurrence is determined at the levels subjectively selected by the entity performing the analysis. In practice, the levels of hazards are adopted, which are specified in PN-EN 50126:2002.

The method similar to the one described above, though less frequently used, is PHA (preliminary hazard analysis) - a method characteristic of the conceptual phase of the system, used to learn new threats and introduce corrections in already existing systems. It is a matrix method in which, unlike the array method, the probability level (P) and the degree of damage (S) are assigned numerical values $(1 \div 10)$, analogously to the FMEA method described below.

The FMEA method (Failure Mode and Effect Analysis) is an inductive method. It assumes damage to the system element, and then performs a subsequent analysis which identifies events that may have been caused by this failure, the main purpose of which is to estimate the frequency and consequences of the component failures. For each identified hazard, numeric values are assigned for the following factors:

- W - probability of a hazard occurring

- $\mathbf{Z}$ - probability of hazard detection

- $\mathbf{S}$ - hazard result.

Then, for each hazard, the number of $\mathrm{R}$ risks is determined, which is the product, i.e. .:

$\mathbf{R}=\mathbf{W} \times \mathbf{Z} \times \mathbf{S}$. Separately, the cases in which the risk for one of the criteria assumes critical values of 9 or 10 (even if the calculated risk product $\mathrm{R}<120$ ) should be analyzed separately. Then, it is also recommended to apply risk reduction measures and to repeat the assessment process after their implementation.

As in the FMEA analysis described above, in the Risk score method the risk level is determined using three parameters: należy aktualizować po każdej przeprowadzonej analizie.

Po wskazaniu wszystkich zagrożeń przez fachowy osąd specjalistycznego kompetentnego zespołu, należy przejść do kolejnego etapu polegającego na wycenie ryzyka, z wykorzystaniem jednej z 3 metod opisanych w tablicy 1. Ryzyka wynikające $\mathrm{z}$ zagrożeń zaklasyfikowane jako zasadniczo dopuszczalne (spełnione jest kryterium, zgodnie z którym ryzyko powinno być na tyle małe, że wprowadzanie jakichkolwiek dodatkowych środków bezpieczeństwa jest nieracjonalne), nie muszą być głębiej analizowane, należy je jednak umieścić w rejestrze zagrożeń.

Przedstawione etapy oceny ryzyka zebrane są i przedstawione także w postaci schematu blokowego w dodatku do rozporządzenia 402/2013 „Proces zarządzania ryzykiem i niezależna ocena".

Z praktyki Instytutu Pojazdów Szynowych „TABOR” wynika, iż najczęściej wykorzystywanym sposobem akceptacji ryzyka, dotyczącym zarówno nowych systemów jak i pojazdów odnawianych lub modernizowanych jest szacowanie i wycena jawnego ryzyka. Warunki konieczne do spełnienia stosowania wspomnianej metody zostały opisane w tablicy 1 . Po wytypowaniu sposobu wyceny jawnego ryzyka, podmiot zamawiający lub producent pojazdu stoi przez wyzwaniem doboru jego konkretnej metody. Rozporządzenie 402/2013 nie narzuca podmiotowi zamawiającemu lub producentowi modernizowanego lub odnawianego pojazdu kolejowego wyboru metody szacowania i wyceny jawnego ryzyka. Ma to być metoda prawidłowo dobrana do ocenianego systemu i jego parametrów (w tym wszystkich trybów pracy). W związku z tym poniżej zestawiono kilka metod mających lub mogących mieć zastosowanie przy wycenie jawnego ryzyka. Metoda tablic jest metodą matrycową opierającą się na dwóch parametrach ryzyka: wagi następstw (skutków) zagrożeń występujących na stanowisku pracy oraz prawdopodobieństwa z jakim następstwa te mogą wystapić. Szacowanie zarówno wagi następstw jak i prawdopodobieństwa ich wystapienia, określa się na poziomach subiektywnie wybranych przez podmiot wykonujący analizę. W praktyce przyjmowane są poziomy zagrożeń, które określono w normie PN-EN 50126:2002.

Metodą zbliżoną do opisanej powyżej, choć rzadziej stosowaną, jest PHA (wstępna analiza zagrożeń) metoda charakterystyczna dla fazy koncepcyjnej systemu, wykorzystywana w celu poznania nowych zagrożeń i wprowadzenia korekt w już istniejących systemach. Jest to metoda matrycowa, w której w przeciwieństwie do metody tabel poziomowi prawdopodobieństwa szkód (P) i poziomowi stopnia szkód (S) przypisywane są wartości liczbowe $(1 \div 10)$, analogicznie jak w opisanej poniżej metodzie FMEA. 
- S - possible outcomes (consequences) of the hazard

- $\mathbf{E}$ - exposure to the hazard

- P - probability of occurrence,

and then, similarly to the FMEA analysis, the risk value $\mathrm{R}$ is determined, which is the product of $\mathbf{R}=\mathbf{S} \times$ $\mathbf{E} \times \mathbf{P}$.

Other risk assessment methods that can potentially be used in the assessment of overt risks include, among others: HAZOP (Hazard and Operability Study), SWIFT (,What - If?”) or quantitative methods: FTA (Fault Tree Analysis) and ETA (Event Tree Analysis).

\section{CONCLUSIONS}

This article is devoted to the risk management process in the context of introducing modernizations of tramway vehicles that possess a valid type approval certificate. Based on the existing railway market experience, the possibility of implementing a risk management process for the modernization of trams was presented and considered.

\section{Bibliography / Bibliografia}

[1] Rozporzqdzenie Ministra Transportu $i$ Gospodarki Morskiej z dnia 28 maja 2013 r. w sprawie homologacji typu tramwajów i trolejbusów (Dz. U. 2015 r. poz. 38)

[2] Rozporzadzenie Ministra Infrastruktury z dnia 2 marca 2011 r. w sprawie warunków technicznych tramwajów $i$ trolejbusów oraz zakresu ich niezbędnego wyposażenia (Dz. U. 2011 r. $n r 65$ Poz. 344)

[3] Ustawa z dnia 28 marca 2003 r. o transporcie kolejowym. Ogłoszenie tekstu jednolitego, Dz. U. 2017 poz. 2117

[4] Rozporzqdzenie Ministra Infrastruktury i Budownictwa $z$ dnia 21 kwietnia 2017 r. w sprawie interoperacyjności systemu kolei (Dz. U. z 2017 r. poz. 934)

[5] Zalecenie komisji z dnia 5 grudnia 2014 r.w sprawie kwestii zwiazanych z dopuszczaniem do eksploatacji $i$ użytkowaniem podsystemów strukturalnych i pojazdów na podstawie dyrektyw Parlamentu Europejskiego $i$ Rady 2008/57/WE i 2004/49/WE

[6] Rozporzqdzenie Wykonawcze Komisji (UE) nr 402/2013 $z$ dnia 30 kwietnia 2013 r. w sprawie wspólnej metody oceny bezpieczeństwa $w$ zakresie wyceny i oceny ryzyka i uchylajace rozporzadzenie (WE) nr 352/2009

[7] Rozporzadzenie komisji (we) nr 352/2009 z dnia 24 kwietnia 2009 r. w sprawie przyjęcia wspólnej metody oceny bezpieczeństwa $w$ zakresie wyceny i oceny ryzyka

[8] Dyrektywa 2004/49/WE parlamentu europejskiego $i$ rady z dnia 29 kwietnia 2004 r. w sprawie bezpieczeństwa kolei wspólnotowych ora zmieniajaca dyrektywe Rady 95/18/WE w sprawie przyznawania licencji przedsiębiorstwom kolejowym, oraz dyrektywe 2001/14/WE $w$ sprawie alokacji zdolności przepustowej infrastruktury kolejowej i pobierania optat za użtkowanie infrastruktury kolejowej oraz certyfikację $w$ zakresie bezpieczeństwa
Metoda FMEA (ang. Failure Mode and Effect Analysis - analiza przyczyn i skutków) jest metodą indukcyjną. Zakłada ona uszkodzenie elementu systemu, a późniejsza analiza identyfikuje zdarzenia, które mogły być spowodowane tą awarią, a której głównym celem jest oszacowanie częstości i skutków uszkodzeń elementu składowego. Dla każdego zidentyfikowanego zagrożenia przypisywane są wartości liczbowe dla następujących czynników:

- W - prawdopodobieństwo wystapienia zagrożenia

- $\mathbf{Z}$ - prawdopodobieństwo wykrycia zagrożenia

- $\mathbf{S}$ - skutek zagrożenia.

Następnie dla każdego zagrożenia wyznaczana jest liczba ryzyka $\mathrm{R}$, będącą iloczynem, $\mathrm{tj}$.:

$\mathbf{R}=\mathbf{W} \times \mathbf{Z} \times \mathbf{S}$. Osobno należy analizować przypadki, w których zagrożenie dla jednego z kryteriów przyjmuje krytyczne wartości 9 lub 10 (nawet, gdy wyznaczony wraz z nimi iloczyn ryzyka $\mathrm{R}<120$ ). Wówczas także zaleca się stosowanie środków redukujących ryzyko i powtórzenie procesu wyceny po ich wdrożeniu.

Podobnie jak w opisanej powyżej analizie FMEA, także i w metodzie Risk score poziom ryzyka określa się za pomocą trzech parametrów:

- S - możliwych skutków (następstw) zagrożenia

- $\mathbf{E}$ - ekspozycji (narażenia) na zagrożenie

- P - prawdopodobieństwa wystąienia zdarzenia, a następnie analogicznie do analizy FMEA wyznaczana jest liczba ryzyka $R$, będącą iloczynem $\mathbf{R}=\mathbf{S} \times \mathbf{E} \times$ $P$.

Do pozostałych metod oceny ryzyka, które można potencjalnie wykorzystać przy wycenie ryzyka jawnego, można zaliczyć między innymi HAZOP (ang. Hazard and Operability Study - Analiza zagrożeń i zdolności operacyjnych), SWIFT (ang. „What - If?”Co - gdyby?") bądź metody ilościowe: FTA (ang. Fault Tree Analysis - Analiza drzewa błędów) oraz ETA (ang. Event Tree Analysis - Analiza drzewa zdarzeń).

\section{PODSUMOWANIE}

Niniejszy artykuł został poświęcony procesowi zarządzania ryzykiem w kontekście wprowadzania modernizacji pojazdów tramwajowych posiadających aktualne świadectwo homologacji. Na podstawie doświadczeń z rynku kolejowego przedstawiono i rozpatrzono możliwość zaimplementowania procesu zarządzania ryzykiem do modernizacji tramwajów.

[1] Rozporzqdzenie Komisji (UE) NR 1302/2014 z dnia 18 listopada 2014 r.w sprawie technicznej specyfikacji interoperacyjności odnoszacej się do podsystemu „Tabor — lokomotywy i tabor pasażerski” systemu kolei w Unii Europejskiej.

[2] PN-EN 50126:2002 Zastosowania kolejowe Specyfikacja niezawodności, dostęności, podatności utrzymaniowej i bezpieczeństwa. 15.09.2002 